\title{
PROPAGASI TIGA VARIETAS MURBEI MELALUI TEKNIK KULTUR JARINGAN
}

\author{
(Propagation of Three Mulberry Varieties \\ by means of Tissue Culture Technique) \\ Nursyamsi \\ Balai Penelitian Kehutanan Makassar \\ Jl. Perintis Kemerdekaan Km. 16,5 Makassar - 90243 \\ Telp. 0411-554049; Fax. 0411-554058
}

Naskah masuk : 1 Juni 2011; Naskah diterima : 4 Mei 2012

\begin{abstract}
Research in Propagation of three mulberry varieties through tissue culture technique aims to determine proper concentration of Benzyl amino purine (BAP) for the propagation of three mulberry (Morus sp.) varieties of KI 14, KI 29 and KI 41. Explants were obtained from auxillary buds of stem branches that were cultured using water medium. Prior to tissue culture experiment, explants were incubated in MSO medium without growth regulator. Explants from three mulberry varieties (KI 14, KI 29, KI 41) were cultured in Murashige and Skoog (MS) added with BAP concentration at 2, 2.5 and $3 \mathrm{mg} / \mathrm{l} \mathrm{for}$ bud induction. Factorial in Completely Randomized Design in 5 replicates was used. The result showed that the fastest bud development was $B_{3} V_{2}$ which obtained in combination treatment between BAP at 3 $\mathrm{mg} / \mathrm{l}$ and KI 29 variety. The most numberous buds were obtained in combination treatment at KI 14 variety and $3 \mathrm{mg} / \mathrm{l}$ BAP, while the longest shoots were obtained in KI 14 variety.
\end{abstract}

Keywords: BAP, tissue culture, mulberry, propagation, varieties

\begin{abstract}
ABSTRAK
Penelitian propagasi tiga varietas murbei melalui kultur jaringan bertujuan untuk mengetahui konsentrasi Benzyl Amino Purin (BAP) yang tepat untuk perbanyakan murbei (Morus sp.) varietas KI 14, KI 29 dan KI 41. Eksplan diperoleh dari tunas aksilar dari cabang yang direndam air. Eksplan ditanam pada media MS0 (Media MS tanpa zat pengatur tumbuh). Rancangan yang digunakan adalah Rancangan Acak Lengkap (RAL) dengan pola faktorial. Faktor I adalah konsentrasi BAP (2, 2,5 dan $3 \mathrm{mg} / \mathrm{l})$. Faktor II adalah varietas murbei (KI 14, KI 29 dan KI 41) dan setiap perlakuan diulang 5 kali. Hasil penelitian menunjukkan bahwa perlakuan yang tercepat bertunas adalah $\mathrm{B}_{3} \mathrm{~V}_{2}$ (BAP $3 \mathrm{mg} / 1$, varietas KI 29), jumlah tunas yang terbanyak diperoleh pada perlakuan varietas KI 14 dan perlakuan BAP konsentrasi $3 \mathrm{mg} / \mathrm{l}$, dan panjang tunas yang tertinggi diperoleh pada varietas KI 14.
\end{abstract}

\section{Kata kunci : BAP, kultur jaringan, murbei, propagation, varietas}

\section{PENDAHULUAN}

Persuteraan alam merupakan rangkaian kegiatan agroindustri yang dimulai dari penanaman murbei (Morus sp.), pembibitan dan pemeliharaan ulat sutera (Bombyx mori), pengolahan kokon menjadi benang hingga menjadi kain. Di Sulawesi Selatan komoditas ini banyak diusahakan bahkan sudah menjadi bagian budaya dan kehidupan masyarakat.
Sulawesi Selatan memiliki lahan yang cukup luas, yaitu sekitar 52\% lahan nasional digunakan untuk pengembangan ulat sutera. Akan tetapi, tidak semua lahan berpotensi mendukung pertumbuhan murbei secara maksimal, karena pada umumnya lahan tanaman murbei terletak pada lereng bukit, tanah masam, kesuburan rendah dan ketersediaan air terbatas sehingga dapat menyebabkan rendahnya produktivitas kebun murbei. 
Produktivitas kebun murbei di Indonesia masih rendah yaitu 8 ton/ha/th dibandingkan produktivitas kebun murbei di RRC yang dapat mencapai 22 ton/ha/th (Sulthoni, 1991). Salah satu usaha untuk meningkatkan produktivitas dari kebun murbei, para pemulia tanaman melalui perbaikan genetik membentuk varietas baru dengan cara hibridisasi terkendali yaitu melalui persilangan antara dua induk yang masingmasing memiliki sifat unggul sehingga diharapkan varietas baru hasil persilangan ini memiliki sifat unggul dari kedua induknya.

Di dunia terdapat berbagai jenis tanaman murbei (Morus sp.), namun yang dianggap unggul di Indonesia adalah sebagai berikut : Morus cathayana, Morus khunpai dan Morus lembang untuk iklim/daerah panas; Morus kanva, Morus kathayana dan Morus multicaulis untuk iklim/ daerah sedang; sedangkan Morus multicaulis dan Morus kanva untuk iklim/daerah dingin.

Kegiatan pemuliaan tanaman murbei di Indonesia telah menghasilkan varietas NI yang mampu berproduksi 18 ton/ha/th (Santoso, 2000). Varietas lain yang telah dihasilkan di Balai Penelitian Kehutanan Makassar adalah varietas KI yang merupakan hasil persilangan antara Morus khunpai dan Morus indica yang tahan terhadap kekeringan. Namun usaha pemuliaan tana-man ini sampai menghasilkan material genetik untuk pengujian di lapangan membutuhkan waktu bertahun-tahun untuk transfer varietas baru ke tahap operasional penanaman.

Kultur jaringan merupakan salah satu metode untuk perbanyakan tanaman yang dapat menghasilkan tanaman baru dalam jumlah yang banyak dan waktu yang relatif singkat. Metode ini yang digunakan sebagai salah satu solusi untuk mempercepat hasil hibridisasi murbei, sehingga transfer hasil-hasil pemuliaan ke pihak operasional tanaman di lapangan dapat dipercepat (Hendaryono dan Ari, 1994).

Keberhasilan perbanyakan tanaman dengan kultur jaringan sangat dipengaruhi oleh adanya peran zat pengatur tumbuh. Salah satu zat pengatur tumbuh yang sering digunakan adalah sitokinin yang berperan menginduksi pertumbuhan tunas aksilar dan tunas adventif yang diperoleh melalui pembelahan sel ke arah memanjang. Golongan sitokinin yang banyak digunakan adalah BAP/BA, kinetin dan 2IP (2- Isopentanyl Adenin) (Hussey,1983; George dan Sherrington, 1984). Kisaran konsentrasi yang umum digunakan yaitu 0,01-10 mg/l (Hartmann $d k k$., 1990). Setiap varietas murbei membutuhkan BAP pada konsentrasi yang berbeda tergantung kepada faktor fisiologis eksplan yang digunakan dalam kultur jaringan. Semakin tua kondisi fisiologis eksplan, semakin tinggi konsentrasi sitokinin yang digunakan, hal ini disebabkan kondisi dinding sel tanaman yang semakin menebal.

Berdasarkan hal tersebut di atas, maka dilakukan penelitian tentang pengaruh berbagai konsentrasi BAP terhadap propagasi tiga varietas murbei melalui kultur jaringan. Tujuan penelitian ini adalah untuk mengetahui konsentrasi BAP yang tepat untuk perbanyakan tiga varietas murbei tanaman dewasa.

\section{METODE PENELITIAN}

\section{A. Waktu dan Tempat Penelitian}

Penelitian ini dilakukan di Laboratorium Kultur Jaringan, Balai Penelitian Kehutanan Makassar.

\section{B. Bahan dan Alat Penelitian}

Bahan-bahan yang digunakan pada penelitian ini adalah sumber eksplan murbei (KI 14, KI 29 dan KI 41). Bahan lain yang digunakan adalah komponen media dasar MS, BAP, NAA, alkohol 96 dan $70 \%$, sodium hyphochlorite 2,5 $\%$, aquadest, Dithane M45 serta Tween 80 .

Alat-alat yang digunakan adalah Laminar air flow cabinet, timbangan analitik, autoklaf, gelas piala, $\mathrm{pH}$ meter, hotplate and magnetic stirer, cawan petri, handsprayer, gelas ukur, erlenmeyer dan alat laboratorium lainnya.

\section{Cara Kerja}

\section{Sterilisasi alat dan sumber eksplan}

Alat-alat seperti pinset, skalpel, petridish, botol kultur dan gunting disterilisasi terlebih dulu sebelum digunakan. Alatalat tersebut dicuci bersih dengan detergen, dikeringanginkan dan dibungkus dengan kertas (kecuali botol kultur) kemudian diautoklaf pada suhu $121{ }^{\circ} \mathrm{C}$ dengan tekanan 1,5 BAR selama 1 jam. Apabila alat-alat tidak langsung digunakan dapat disimpan di oven pada suhu $70^{\circ} \mathrm{C}$. Laminar air flow cabinet sebelum digunakan terlebih dulu dibersihkan dengan alkohol 70\% dan dinyalakan lampu Ultra violetnya selama 1 jam.

Sumber eksplan adalah cabang induk tanaman dewasa yang berumur 2 tahun yang diambil dari lapangan kemudian ditumbuhkan secara rejuvinasi. Eksplan diperoleh dari mata tunas aksilar yang ditumbuhkan tunasnya melalui 
kultur jaringan pada media Ms0. Eksplan yang akan ditumbuhkan tunasnya terlebih dulu disterilisasi. Cabang yang terpilih disterilkan dengan cara cabang dicuci dengan detergen sampai bersih, direndam dalam fungisida Dithane M45 dengan konsentrasi 2 gr/l selama 15 menit kemudian dibilas dengan air kran hingga bersih. Sterilisasi selanjutnya dilakukan dalam laminar air flow cabinet. Cabang-cabang ini semprot dengan alkohol $70 \%$ dan direndam dalam sodium hyphochlorit $2,5 \%$ yang ditambah tween 80 sebanyak 1 tetes selama 10 menit, kemudian dibilas dengan aquadest steril 3 kali. Eksplan yang telah disterilkan ditanam dalam medium MS0, setiap botol kultur diisi 3 - 4 mata tunas dan diletakkan di ruang inkubasi.

\section{Pembuatan media}

Untuk memudahkan pekerjaan dibuat larutan stok dari komposisi media dasar MS. Larutan dikelompokkan dalam stok hara makro, mikro, vitamin dan zat pengatur tumbuh. Media perlakuan dibuat dengan cara setiap larutan stok dipipet sesuai dengan keperluan dan dimasukkan ke dalam gelas piala $1.000 \mathrm{ml}$. Larutan stok tersebut ditambahkan zat pengatur tumbuh sesuai perlakuan. Semua perlakuan juga ditambahkan NAA $0,1 \mathrm{mg} / \mathrm{l}$. Larutan gula dan aquadest steril ditambahkan hingga volume mencapai $900 \mathrm{ml}$. Setelah semua tercampur, $\mathrm{pH}$ larutan diukur hingga 5,8 dengan menambahkan $\mathrm{NaOH} 0,1 \mathrm{M}$ atau $\mathrm{Hcl} 0,1 \mathrm{M}$. Volume nutrisi dicukupkan hingga $1.000 \mathrm{ml}$ kemudian ditambahkan agaragar dan dipanaskan di atas hotplate and magnetic stirer hingga larut. Larutan media kemudian dimasukkan ke dalam botol-botol kultur, setiap botol diisi kurang lebih $20 \mathrm{ml}$ lalu ditutup dengan aluminium foil, selanjutnya disterilkan dalam autoklaf pada suhu $121^{\circ} \mathrm{C}$ dengan tekanan 1,5 BAR selama 15 menit.

\section{Penanaman}

Tunas yang tumbuh dari hasil inisiasi awal yang digunakan sebagai bahan untuk subkultur disebut eksplan. Eksplan yang berumur kurang lebih 4 minggu panjang $3 \mathrm{~cm}$, dipotong setiap mata tunasnya dan ditanam pada media perlakuan. Setiap media perlakuan ditanam satu mata tunas dan disimpan pada ruang inkubasi untuk selanjutnya dilakukan pengamatan respon tunas akibat perlakuan.

\section{Rancangan Percobaan}

Rancangan yang digunakan adalah Rancangan Acak Lengkap dengan pola faktorial.
Faktor I adalah konsentrasi BAP yang terdiri dari :

$$
\begin{aligned}
& \mathrm{B}_{1}=\text { BAP konsentrasi } 2 \mathrm{mg} / 1 \\
& \mathrm{~B}_{2}=\text { BAP konsentrasi } 2,5 \mathrm{mg} / 1 \\
& \mathrm{~B}_{3}=\text { BAP konsentrasi } 3 \mathrm{mg} / 1
\end{aligned}
$$

Faktor II adalah varietas murbei yang terdiri dari :

$\mathrm{V}_{1}=$ Varietas KI 14

$\mathrm{V}_{2}=$ Varietas KI 29

$\mathrm{V}_{3}=$ Varietas KI 41

Jumlah kombinasi perlakuan ada 9 dan setiap perlakuan diulang 5 kali. Parameter yang diamati adalah kecepatan pembentukan tunas yang diamati setiap hari, jumlah tunas dan tinggi tunas diamati pada akhir pengamatan yaitu 8 minggu setelah tanam.

\section{E. Analisis Data}

Data hasil pengamatan dianalisis dengan analisis varian dari Rancangan Acak Lengkap dengan pola faktorial. Jika hasil sidik ragam yang diperoleh berbeda nyata maka dilakukan uji lanjutan yaitu Uji Beda Jarak Berganda Duncan (DMRT).

\section{HASIL DAN PEMBAHASAN}

\section{A. Kecepatan Pembentukan Tunas}

Berdasarkan analisis sidik ragam (Lampiran 1) kecepatan pembentukan tunas menunjukkan bahwa interaksi antara konsentrasi BAP dan varietas murbei berpengaruh sangat nyata terhadap kecepatan pembentukan tunas sedangkan perlakuan tunggal varietas dan BAP tidak berpengaruh nyata.

Hasil uji lanjut DMRT interaksi konsentrasi BAP dan varietas murbei terhadap kecepatan pembentukan tunas disajikan pada Tabel 1 .

Hasil uji DMRT menunjukkan adanya interaksi perlakuan $\mathrm{B}_{3} \mathrm{~V}_{2}$ yaitu varietas KI 29 yang ditanam pada media yang mengandung BAP konsentrasi $3 \mathrm{mg} / \mathrm{l}$ dan NAA $0,1 \mathrm{mg} / 1$ membentuk tunas tercepat diantara semua perlakuan yaitu rata-rata 3,6 hari. Hasil ini tidak berbeda nyata dengan perlakuan lainnya kecuali dengan perlakuan $\mathrm{B}_{1} \mathrm{~V}_{1}$ (interaksi antara $\mathrm{BAP}$ konsentrasi $2 \mathrm{mg} / 1$ ditambahkan NAA 0,1 mg/l dengan KI 14). Secara umum semua perlakuan membentuk tunas sebelum eksplan berumur seminggu, ini menunjukkan bahwa tanaman murbei mudah untuk dikulturkan. 
Tabel(Table) 1. Pengaruh interaksi konsentrasi BAP dengan tiga varietas murbei terhadap kecepatan pembentukan tunas (Interaction effect of BAP concentration and mulberry varieties on shootformation)

\begin{tabular}{|c|c|}
\hline $\begin{array}{c}\text { Perlakuan } \\
\text { (Treatment) }\end{array}$ & $\begin{array}{c}\text { Kecepatan Pembentukan Tunas/Hari } \\
\text { (Rate of Shoot Formation/Days) }\end{array}$ \\
\hline $\mathrm{B}_{3} \mathrm{~V}_{2}$ & $3,6 \mathrm{a}$ \\
$\mathrm{B}_{2} \mathrm{~V}_{3}$ & $3,8 \mathrm{a}$ \\
$\mathrm{B}_{3} \mathrm{~V}_{1}$ & $4 \mathrm{a}$ \\
$\mathrm{B}_{1} \mathrm{~V}_{3}$ & $4 \mathrm{a}$ \\
$\mathrm{B}_{1} \mathrm{~V}_{2}$ & $4,2 \mathrm{a}$ \\
$\mathrm{B}_{2} \mathrm{~V}_{2}$ & $4,2 \mathrm{a}$ \\
$\mathrm{B}_{2} \mathrm{~V}_{1}$ & $4,4 \mathrm{ab}$ \\
$\mathrm{B}_{3} \mathrm{~V}_{3}$ & $5 \mathrm{ab}$ \\
$\mathrm{B}_{1} \mathrm{~V}_{1}$ & $5,6 \mathrm{~b}$ \\
\hline
\end{tabular}

Keterangan (Remarks): Angka-angka diikuti huruf yang sama berbeda tidak nyata pada taraf uji 0,01 (Values followed by the same letter are not significantly different at 0.01)

Perlakuan yang paling cepat membentuk tunas adalah varietas murbei KI 29 yang ditanam pada media yang mengandung BAP konsentrasi 3 $\mathrm{mg} / \mathrm{l}$ dan NAA $0,1 \mathrm{mg} / \mathrm{l}$. Hal ini menunjukkan untuk varietas murbei KI 29, konsentrasi $3 \mathrm{mg} / 1$ yang ditambah NAA $0,1 \mathrm{mg} / \mathrm{l}$ adalah konsentrasi yang tepat untuk pembentukan tunas. Menurut Pierik (1987) pertumbuhan dan perkembangan mata tunas menjadi tunas sangat ditentukan oleh ketepatan konsentrasi dan jenis sitokinin. Pemberian sitokinin ke dalam media dapat merangsang pembentukan pucuk aksilar melalui pengurangan dominasi apikal. Pembentukan tunas dapat dirangsang dengan pemberian sitokinin dengan konsentrasi yang tinggi dan sebaliknya pemberian auksin yang rendah atau tanpa auksin.

\section{B. Jumlah Tunas}

Hasil sidik ragam (Lampiran 2) menunjukkan faktor tunggal (varietas murbei dan konsentrasi BAP) berpengaruh terhadap jumlah tunas yang terbentuk, sedangkan interaksi antara keduanya tidak berpengaruh terhadap jumlah tunas yang terbentuk. Adapun hasil uji DMRT untuk jumlah tunas yang terbentuk pada berbagai varietas disajikan pada Tabel 2.

Tabel (Table) 2. Rata-Rata jumlah tunas yang terbentuk pada berbagai varietas (The average of shoot number in some varieties)

\begin{tabular}{|c|c|}
\hline Perlakuan Varietas ( Variety Treatment) & Jumlah Tunas (Shoot Number) \\
\hline K1 41 & 7,47 a \\
KI 29 & 8,87 b \\
KI 14 & $10,2 \quad \mathrm{c}$ \\
\hline
\end{tabular}

Keterangan (Remarks): Angka-angka diikuti huruf yang sama berbeda tidak nyata pada taraf uji 0,05 (Values followed by the same letter are not significantly different at 0.05)

Jumlah tunas yang terbanyak dicapai oleh varietas KI 14 dan hasil ini berbeda dengan varietas yang lain. Varietas KI 41 menghasilkan jumlah tunas yang terendah yaitu rata-rata 7,47 tunas. Hal ini menunjukkan bahwa dari 3 varietas $\mathrm{KI}$, varietas KI 14 memberikan hasil yang terbaik dalam perbanyakan tanaman murbei secara kultur jaringan.

Hasil uji DMRT untuk rata-rata jumlah tunas yang terbentuk pada berbagai konsentrasi BAP disajikan pada Tabel 3.
Hasil uji DMRT pada Tabel 3 nampak jumlah tunas yang terbanyak pada perlakuan BAP konsentrasi $3 \mathrm{mg} / \mathrm{l}$ ditambah NAA 0,1 mg/l. Rata-rata jumlah tunas yang dihasilkan adalah 9,67 tunas. Hasil ini tidak berbeda dengan perlakuan B2 (BAP konsentrasi 2,5 $\mathrm{mg} / \mathrm{l}$ ditambah NAA $0,1 \mathrm{mg} / 1$, tetapi berbeda nyata dengan perlakuan B1 (BAP konsentrasi $2 \mathrm{mg} / 1$ ditambah NAA $0,1 \mathrm{mg} / \mathrm{l})$.

Hasil ini hampir sama dengan hasil penelitian yang telah dilakukan oleh Suhartati 
Tabel(Table) 3. Pengaruh konsentrasi BAP terhadap jumlah tunas murbei yang terbentuk (Effect of BAP concentration on shoot number of mulberry)

\begin{tabular}{|c|c|}
\hline Perlakuan Konsentrasi BAP & Jumlah Tunas \\
(BAP concentration Treatment) & (Shoot Number) \\
\hline $\mathrm{B}_{1}(2 \mathrm{mg} / \mathrm{l})$ & $8,07 \mathrm{a}$ \\
$\mathrm{B}_{2}(2,5 \mathrm{mg} / \mathrm{l})$ & $8,87 \mathrm{ab}$ \\
$\mathrm{B}_{3}(3 \mathrm{mg} / \mathrm{l})$ & $9,67 \mathrm{~b}$ \\
\hline
\end{tabular}

Keterangan(Remarks): Angka-angka diikuti huruf yang sama berbeda tidak nyata pada taraf uji 0,05 (Values followed by the same letter are not significantly different at 0.05 )

(2001) pada tanaman bitti (Vitex sp.). Penggunaan sitokinin jenis BAP pada konsentrasi 1 - 5 $\mathrm{mg} / \mathrm{l}$ yang ditambah NAA $0,1 \mathrm{mg} / \mathrm{l}$ merupakan kombinasi yang baik untuk pertumbuhan tunas tanaman bitti. Menurut Nasir (1992) dalam Suhartati (2001) pertumbuhan tunas rambutan dapat dirangsang dengan menggunakan BAP konsentrasi $2 \mathrm{mg} / 1$ merupakan kombinasi yang efektif diantara semua perlakuan.

Berdasarkan hasil pengamatan pada semua perlakuan, ditemukan semua tanaman terbentuk kalus dan tidak ada satupun yang membentuk akar. Hal ini disebabkan pemberian zat pengatur tumbuh BAP dengan konsentrasi yang relatif tinggi dibandingkan konsentrasi zat pengatur tumbuh NAA sehingga menyebabkan terhambatnya pembentukan akar dan sebaliknya merangsang pembentukan tunas. Hal ini sesuai pendapat Winata (1995), mengemukakan bahwa penggunaan BAP pada konsentrasi yang tinggi sering menyebabkan plantlet sulit berakar.

Zat pengatur tumbuh sitokinin dan auksin yang diproduksi secara endogen dengan kadar yang seimbang pada tanaman, tidak bekerja secara sendiri-sendiri tetapi bekerja secara berinteraksi untuk pertumbuhan dan perkem- bangan tanaman tersebut. Namun penambahan zat pengatur tumbuh dari luar dapat menyebabkan terhambatnya pertumbuhan salah satu bagian tanaman dan merangsang pertumbuhan bagian tanaman yang lain (Abidin, 1985).

Sitokinin dalam kultur jaringan ber-pengaruh terutama pada pembelahan sel dan bersama-sama dengan auksin memberikan pengaruh interaksi terhadap diferensiasi jaringan. Pada pemberian auksin dengan kadar yang relatif tinggi maka diferensiasi kalus cenderung ke arah primordial akar, sedangkan pada pemberian sitokinin dengan kadar yang relatif tinggi, diferensiasi kalus cenderung ke arah primordial batang dan tunas (Hendaryono dan Ari, 1994).

\section{Tinggi Tanaman}

Analisis sidik ragam (Lampiran 3) menunjukkan bahwa faktor tunggal varietas murbei berpengaruh sangat nyata terhadap tinggi plantlet. Faktor konsentrasi BAP dan interaksi antara konsentrasi BAP dengan varietas murbei tidak berpengaruh nyata terhadap tinggi plantlet. Hasil uji DMRT tinggi plantlet murbei pada ketiga varietas disajikan pada Tabel 4.

Tabel(Table) 4. Rata-rata tinggi plantlet murbei pada tiga varietas murbei (The average height of plantlet in three mulberry varieties)

\begin{tabular}{|c|c|}
\hline Varietas (Varieties) & Tinggi Tanaman $(\mathrm{cm})$ (Shoot height) $(\mathrm{cm})$ \\
\hline KI 41 & $1,97 \mathrm{a}$ \\
KI 29 & $3,00 \mathrm{~b}$ \\
KI 14 & $5,47 \mathrm{c}$ \\
\hline
\end{tabular}

Keterangan(Remarks): Angka-angka diikuti huruf yang sama berbeda tidak nyata pada taraf uji 0,05 (Values followed by the same letter are not significantly different at 0.05)

Hasil uji DMRT pada Tabel 4 memperlihatkan tinggi plantlet yang tertinggi ditemukan pada varietas KI 14 yaitu rata-rata 5,47 tunas dan berbeda dengan varietas-varietas yang lain. Tinggi plantlet yang terendah ditemukan pada murbei varietas KI 41.

Hasil pengamatan selama 8 minggu penelitian, terlihat tinggi plantlet berkaitan dengan jumlah tunas yang dihasilkan. Semakin banyak tunas yang dihasilkan oleh tanaman tersebut, maka akan semakin pendek tunas yang dihasilkan tanaman tersebut.

Nursyamsi dan Santoso (2002), menyatakan semakin tinggi jumlah tunas maka tunas yang terbentuk makin pendek. Hal ini disebabkan unsur-unsur hara terdapat pada media diman- 
faatkan oleh banyak tunas sehingga tiap tunas hanya memperoleh unsur hara yang sedikit dibandingkan perlakuan yang menghasilkan jumlah tunas yang sedikit.

\section{KESIMPULAN}

1. Kombinasi perlakuan murbei zat pengatur tumbuh BAP $3 \mathrm{mg} / 1$ dengan varietas KI 29 menunjukkan waktu tercepat (3-4 hari) untuk kecepatan pembentukan tunas.

2. Media yang terbaik untuk perbanyakan jumlah tunas adalah media MS yang ditambah BAP $3 \mathrm{mg} / \mathrm{l}$.

3. Varietas murbei yang menghasilkan pertumbuhan tunas terpanjang dan terbanyak adalah varietas KI 14, sehingga varietas KI 14 merupakan varietas yang menjanjikan untuk dikembangkan dengan teknik kultur jaringan.

\section{DAFTAR PUSTAKA}

Abidin, Z. 1985. Dasar-dasar Pengetahuan Tentang Zat Pengatur Tumbuh. PT. Angkasa. Bandung.

George, E.F. dan P.D. Sherrington. 1984. Plant Propagation by Tissue Culture. Exegetics Ltd. Eversley.

Gunawan. L.W. 1987. Teknik Kultur Jaringan. Institut Pertanian Bogor. Bogor.

Hartmann, H.T., D.E. Kester dan F.T. Davies. 1990. Plant Propagation and Principles Practices. Prentice-Hall Inc., New Jersey.
Hendaryono, D.P.S. dan W. Ari. 1994. Teknik Kultur Jaringan, Pengenalan dan Petunjuk Perbanyakan Tanaman Secara Vegetatif Modern. Penerbit Kanisius. Yogyakarta.

Hussey,G. 1983. In Vitro Propagation of Horticultural and Agricultural Crops. P.111135. In. S.H. Mantell and H. Smith (ed.). Plant Biotechnology. Cambridge Univ. Press. Sydney.

Nursyamsi dan B. Santoso. 2002. Multiplikasi Murbei Varietas NU 11 pada Berbagai Konsentrasi BAP Melalui Kultur Jaringan. Buletin Penelitian dan Pengembangan Kehutanan. Vol. 8. Makassar.

Pierik, R.I.M. 1987. In Vitro Culture of Higher Plant. Marthinus Niijhioff Publishe. Dordecht.

Santoso, B. 2000. Pemuliaan Tanaman Murbei untuk Ulat Sutera. Prosiding Seminar Nasional Status Silvikultur. Fakultas Kehutanan. Universitas Gadjah Mada. Yogyakarta.

Suhartati. 2001. Perbanyakan Bitti (Vitex sp.) Secara In Vitro pada Berbagai Kombinasi Zat Pengatur Tumbuh. UNHAS. Makassar.

Sulthoni, A. 1991. Peranan Entomologi Hutan dan Tantangannya Menghadapi Pembangunan Hutan Tanaman Industri. Pidato Pengukuhan Guru Besar dalam Ilmu Hama Tanaman. Fakultas Kehutanan Universitas Gadjah Mada. Yogyakarta.

Winata, L. 1995. Teknik Kultur In Vitro dalam Hortikultura. PT. Penebar Swadaya. Jakarta. 
Lampiran (Appendix) 1. Sidik ragam kecepatan pertumbuhan tunas (Analysis of variance rate of shoot formation)

\begin{tabular}{|c|c|c|c|c|c|c|}
\hline \multirow{2}{*}{$\begin{array}{c}\text { Sumber Variasi } \\
\text { (Source of Variance) }\end{array}$} & \multirow{2}{*}{$\begin{array}{l}\mathrm{Db} \\
(d f)\end{array}$} & \multirow{2}{*}{$\begin{array}{l}\mathrm{JK} \\
(S S)\end{array}$} & \multirow{2}{*}{$\begin{array}{l}\mathrm{KT} \\
(M S)\end{array}$} & \multirow{2}{*}{$\begin{array}{l}\text { F. Hit } \\
\text { (F. Calc) }\end{array}$} & \multicolumn{2}{|c|}{ F. Tabel } \\
\hline & & & & & 0,05 & 0,01 \\
\hline Perlakuan (Treatment) & & & & & & \\
\hline Konsentrasi BAP (B) & 2 & 3,38 & 1,69 & $1,79^{* *}$ & 3,26 & 5,25 \\
\hline Varietas (V) & 2 & 1,91 & 0,96 & $1,01^{* *}$ & 3,26 & 5,25 \\
\hline Interaksi B x V & 4 & 10,36 & 2,59 & $2,74^{\mathrm{ns}}$ & 2,62 & 3,89 \\
\hline Galat (Error) & 36 & 36 & 0,94 & & & \\
\hline Total (Total) & 44 & 49,64 & 886 & & & \\
\hline
\end{tabular}

Keterangan (Remarks): $* *=$ nyata (Significant)

= non significant (non Significant)

Lampiran (Appendix) 2. Sidik ragam jumlah tunas (Analysis of variance of shoot number)

\begin{tabular}{|l|c|c|c|c|c|c|}
\hline \multicolumn{1}{r|}{$\begin{array}{c}\text { Sumber Variasi } \\
\text { (Source of Variance) }\end{array}$} & $\begin{array}{c}\text { Db } \\
(d f)\end{array}$ & JK & KT & \multicolumn{2}{|c|}{ F. Hit } & \multicolumn{2}{c|}{ F. Tabel } \\
\cline { 6 - 8 } & $(S S)$ & $(M S)$ & & (F. Calc.) & 0,05 & 0,01 \\
\hline Perlakuan (Treatment) & & & & & & \\
Konsentrasi BAP (B) & 2 & 56,04 & 28,02 & $9,97^{* *}$ & 4,26 & 7,82 \\
Varietas (V) & 2 & 19,24 & 9,62 & $3,43^{* *}$ & 3,40 & 5,61 \\
Interaksi B x V & 4 & 13,42 & 3,36 & $1,194^{\text {ns }}$ & 3,40 & 5,61 \\
Galat (Error) & 36 & 189,91 & 2,81 & & & \\
Total (Total) & 44 & 3710 & & & & \\
\hline
\end{tabular}

Keterangan (Remarks): * ${ }^{*}=$ sangat nyata (Highly Significant)

$$
\text { = non significant (non Significant) }
$$

Lampiran (Appendix) 3. Sidik ragam tinggi tunas (Analysis of variance of shoot height)

\begin{tabular}{|c|c|c|c|c|c|c|}
\hline \multirow{2}{*}{$\begin{array}{c}\text { Sumber Variasi } \\
\text { (Source of Variance) }\end{array}$} & \multirow{2}{*}{$\begin{array}{l}\mathrm{Db} \\
(d f)\end{array}$} & \multirow{2}{*}{$\begin{array}{c}\mathrm{JK} \\
(S S)\end{array}$} & \multirow{2}{*}{$\begin{array}{l}\mathrm{KT} \\
(M S)\end{array}$} & \multirow{2}{*}{$\begin{array}{c}\text { F. Hit } \\
\text { (F.Calc) }\end{array}$} & \multicolumn{2}{|c|}{ F. Tabel } \\
\hline & & & & & 0,05 & 0,01 \\
\hline Perlakuan (Treatment) & & & & & & \\
\hline Konsentrasi BAP (B) & 2 & 96,86 & 48,43 & $28,54 * *$ & 4,26 & 7,82 \\
\hline Varietas (V) & 2 & 0,62 & 0,31 & $0,18^{\mathrm{ns}}$ & 3,40 & 5,61 \\
\hline Interaksi B x V & 4 & 13,27 & 3,32 & $1,96^{\mathrm{ns}}$ & 3,40 & 5,61 \\
\hline Galat (Error) & 36 & 61,10 & 1,70 & & & \\
\hline Total (Total) & 44 & 716,46 & & & & \\
\hline
\end{tabular}

Keterangan (Remarks): ** = sangat nyata (Highly Significant)

$=$ non significant (non Significant) 


\section{Lampiran 4.}

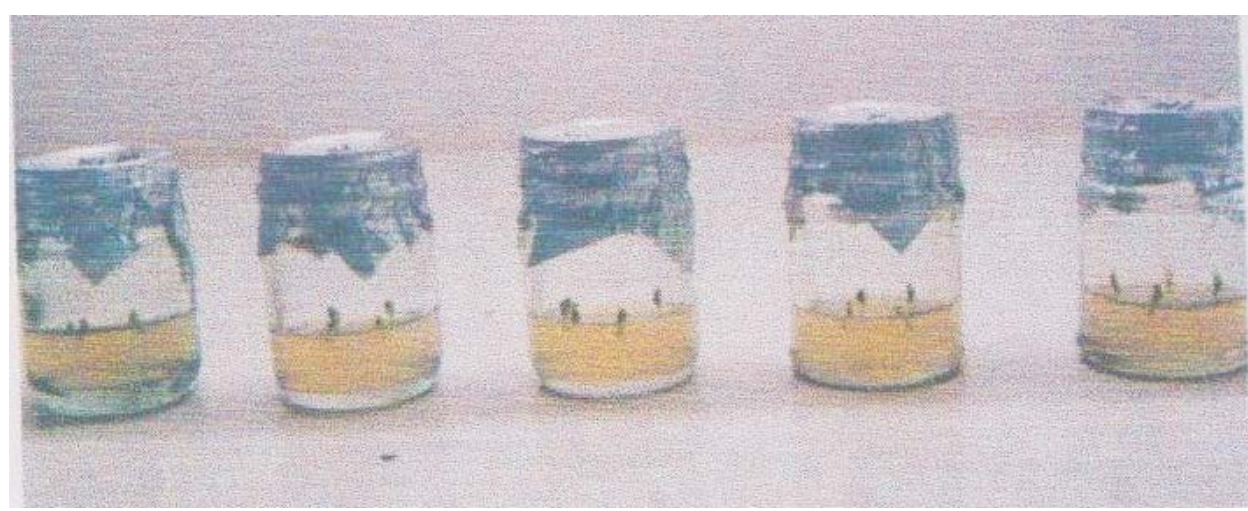

Gambar (figure) 1. Eksplan yang ditanam pada media $\mathrm{M}_{5} 0$ (Explans were planted on MSO medium)

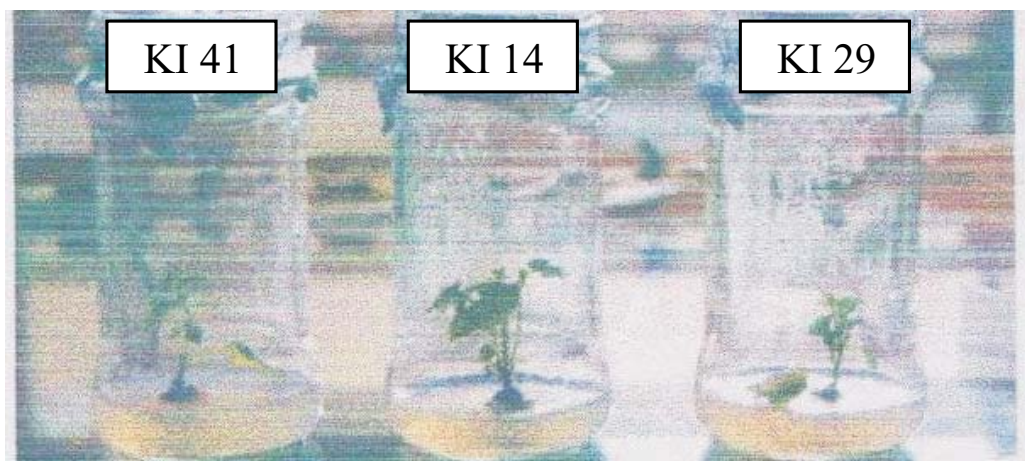

Gambar(figure) 2. Pertumbuhan tunas dari ketiga varietas murbei pada media BAP $3 \mathrm{mg} / 1$ (The growth of shoots from three varieties of mulberry on BAP $3 \mathrm{mg} / \mathrm{l}$ medium) 